\title{
Outcome of Continuous Peritoneal Dialysis in Patient with Acute Kidney Injury
}

\section{Amrit KC ${ }^{1}$, Rahman Tanvir ${ }^{2}$, Alam Muhammad Rafiqul ${ }^{3}$, Ahmed A. H. Hamid ${ }^{3}$, Noor Towhida}

${ }^{1}$ Department of Medicine, Pokhara Academy of Health Sciences, Pokhara, Nepal

${ }^{2}$ Department of Nephrology, United Hospital Private Hospital, Dhaka, Bangladesh

${ }^{3}$ Department of Nephrology, Bangabandhu Sheikh Mujib Medical University, Dhaka, Bangladesh

\section{Correspondence:}

Dr. Amrit K.C, M.D,

Department of Medicine,

Pokhara Academy of Health Sciences, Western

Regional Hospital, Pokhara, Nepal

Email: omritkc@gmail.com

Article received : $9^{\text {th }}$ April 2018

Article accepted : $10^{\text {th }}$ Oct. 2018

\section{ABSTRACT}

Background: Though peritoneal dialysis has several limitations, it is still used in acute kidney injury (AKI) patients as an alternative method of Renal Replacement Therapy (RRT), especially in low socioeconomic countries. Materials and Method: This study included thirty patients diagnosed as AKI. Peritoneal access was established through flexible Tenckhoff catheter for Continuous Peritoneal Dialysis (CPD) and 6-8 exchanges were done in 24 hours. Results: Among 30 patients mean age was (mean \pm SD) $49.93 \pm 14.42$ years. Seven $(23.33 \%$ ) patients were hemodynamically unstable. The cause of AKI was drug induced in 6(20.7\%), hypovolemia/Acute Tubular Necrosis in 6(20.0\%), sepsis in 5(16.7\%), heart failure in $2(6.7 \%)$ and $11(36.7 \%)$ had multiple causes. In initial presentation, mean serum creatinine was $683.42 \mu \mathrm{mol} / \mathrm{L}$, and the number of sessions required for stabilization of serum creatinine was $7.5 \pm 1.43$, sessions required for correction of hyperkalemia and metabolic acidosis were $2.15 \pm 0.69$ and $2.5 \pm 0.76$ respectively. The delivered $\mathrm{Kt} / \mathrm{V}$ urea was $1.95 \pm 0.14$ weekly. Six $(20.0 \%)$ patients had peritonitis, five $(16.7 \%)$ had pericatheter leakage and four (13.33\%) had catheter blockage. Among 30 patients, three patients $(10 \%)$ had died, sixteen $(59.3 \%)$ had recovery of renal function and rest did not recover renal function. Conclusion: CPD was effective for correction of metabolic and electrolyte imbalance.

Key words: Acute Kidney Injury, Continuous Peritoneal Dialysis, Renal Replacement Therapy

\section{INTRODUCTION:}

Acute kidney injury (AKI) is a syndrome characterized by a sudden deterioration in renal function over several hours to several weeks. AKI requiring Renal Replacement Therapy (RRT) occurs in approximately $1 \%$ to $2 \%$ of hospitalized patients and in $6 \%$ to $7 \%$ of critically ill patients ${ }^{1}$. Severe or life threatening AKI demands a form of renal replacement therapy (RRT) that is initiated to return the parameters of the body's internal milieu to normal.

Continuous peritoneal dialysis (CPD) has many potential advantages. It is technically simple with minimal 
infrastructure requirements. Here solute removal is gradual with less potential risk for disequilibrium syndrome. Since no extracorporeal circulation is required, there is relatively good hemodynamic tolerance and residual renal function all may be better preserved. So interest in using CPD to manage AKI patients has been increasing.

Continuous peritoneal dialysis and daily hemodialysis both are effective for treating AKI patients and are similar with regard to survival rate, recovery of kidney function and metabolic control ${ }^{2}$. The objective of this study was to assess the effectiveness of CPD as a form of renal replacement therapy in AKI and to observe the outcome and mechanical complications.

\section{MATERIALS AND METHODS:}

This was an observational study carried out in the Department of Nephrology, Bangabandhu Sheikh Mujib Medical University, Dhaka, Bangladesh from January 2015 to September 2016.Patients with clinical and laboratory criteria of AKI \{According to Acute Kidney Injury Network (AKIN) criteria $\}$ and had indication for RRT were included in this study. Indications for commencing dialysis were symptomatic uremia, hyperkalemia (serum potassium $>6.5 \mathrm{mmol} / \mathrm{l}$ ), severe metabolic acidosis $(\mathrm{pH}<7.15)$, fluid overload, oliguria (urine output $<0.3 \mathrm{ml} / \mathrm{kg}$ for 24 hours). Patients unwilling to give consent, age below 18 years, chronic kidney disease (CKD) stage 4 and 5, urinary tract obstruction, pregnancy, recent abdominal surgery ( $<1$ month), prerenal AKI, rapidly progressive glomerulonephritis (RPGN) were excluded.

After evaluation by history, physical examination and laboratory investigations, patients who were diagnosed as AKI and had indication of RRT (as mentioned previously) were included. Effectiveness of peritoneal dialysis was determined by formula for $\mathrm{Kt} / \mathrm{V}$, where $\mathrm{K}=$ dialyzer clearance of urea, $\mathrm{t}=$ duration of dialysis, $\mathrm{V}=$ volume of distribution of urea. At the beginning of each dialysis session serum creatinine; serum electrolytes and ABG analysis were done. Dialysate fluid $(10 \mathrm{ml})$ was taken for measurement of urea from each bag. When peritonitis was suspected dialysate fluid was taken and sent for cytology and culture sensitivity.

CPD was discontinued temporarily for spacing or observation in case of

Partial recovery or stabilization of renal function as defined below:

-Restoration of diuresis (gradually increase to more than $1000 \mathrm{~mL}$ urine in 24 hours),

-A progressive fall in serum creatinine $(<353 \mu \mathrm{mol} / \mathrm{L})$,

-Change of dialysis method (i.e. hemodialysis),

-The death of the patient,

-Absence of recovery of renal functions after 30 days. Patients with no recovery of renal function were kept on dialysis and those with stabilized renal function were followed up for at least two weeks before removal of Tenckhoff catheter. At the time of discharge they were advised to come for follow-up at the end of $1^{\text {st }}, 2^{\text {nd }}$ and $3^{\text {rd }}$ month and at each visit they were assessed for recovery of renal function. Finally, the patients were labeled as renal recovery or no recovery.

Recovery of renal function was defined as:

Serum creatinine level less than $1.3 \mathrm{mg} / \mathrm{dl}$

Serum Urea level less than $40 \mathrm{mg} / \mathrm{dl}$

Serum sodium level 135-145mmol/L

Serum potassium level between $3.5-4.5 \mathrm{mmol} / \mathrm{L}$ and Urine output more than $0.5 \mathrm{ml} / \mathrm{kg} / \mathrm{hr}$

The result was presented as mean \pm SD or median, according to normality characteristics of each variable with $5 \% \quad(\mathrm{p}<0.05)$ significance level. To compare parametric variables paired t-test was used. Data was analyzed using Statistical Package for Social Science (SPSS) v 22.0 (Chicago, IL) software.

\section{RESULTS:}

Table 1 shows the basic characteristic of the patients at the time of enrolment. Mean age of the patients was 49.93 years. Male was $66.7 \%$ and female $33.3 \%$. Weight was $62.4 \pm 4.61 \mathrm{~kg}$ (mean \pm SD). Mean SBP was $112.0 \mathrm{~mm} \mathrm{Hg}$ and DBP $64.8 \mathrm{~mm} \mathrm{Hg}$. Seven patients were hemodynamically unstable. Mean urine volume was $383.6 \mathrm{ml}$ in 24 hours. The cause of AKI was drug induced in $6(20.0 \%)$ patients, hypovolemia/Acute Tubular Necrosis (ATN) in 6(20.0\%) patients, sepsis in $5(16.67 \%)$ patients, heart failure in $2(6.7 \%)$ patients and $11(36.7 \%)$ had multiple causes. The co-morbidities were as follows: 11(36.7\%) patients had Diabetes Mellitus, 9(30\%) Hypertension, 9(30\%) Chronic Kidney Disease, 9(30\%) Ischemic Heart Disease and 3(10\%) 
patients had cerebrovascular disease. Majority of the patients had uremic symptoms 26(86.7\%), followed by in descending order oliguria 14(46.7\%), hyperkalemia (>6.5 mmol/L) 13(43.3\%), fluid overload 7(23.3\%) and metabolic acidosis $8(26.7 \%)$ cases.

Table 2 shows outcomes of CPD in AKI patients and Table 3. Shows number of CPD session required to reduce serum creatinine, urea, potassium and severe metabolic acidosis. Table 4 reveals recovery of the renal function estimated by serum creatinine level at the end of 4,8 and 12 week.

Table1. Baseline characteristics of the AKI patients at the time of enrollment $(n=30)$

\begin{tabular}{|l|l|}
\hline \multicolumn{1}{|c|}{ Variables } & \multicolumn{1}{|c|}{ Values } \\
\hline Age (years) & $49.93 \pm 14.42$ \\
\hline Male sex & $20 / 30(66.7 \%)$ \\
\hline Weight $(\mathrm{kg})$ & $62.4 \pm 4.61$ \\
\hline Blood pressure $(\mathrm{mmHg}):$ & $112.0 \pm 22.7$ \\
SBP Mean $\pm \mathrm{SD}$ & $64.8 \pm 12.1$ \\
DBP Mean \pm SD & $7 / 30(23.3 \%)$ \\
Hemodynamically unstable & $683.4 \pm 68.4$ \\
\hline At onset of dialysis: & \\
Serum creatinine $(\mu \mathrm{mol} / \mathrm{L})$ & $6 / 30(20.0 \%)$ \\
\hline Etiology of AKI: & $6 / 30(20.0 \%)$ \\
Drug induced & $5 / 30(16.67 \%)$ \\
Hypovolemia & $2 / 30(6.7 \%)$ \\
Sepsis & $11 / 30(36.7 \%)$ \\
Heart failure & \\
Mixed/multiple & \\
\hline Indication for the initiation of & $26(86.7 \%)$ \\
dialysis: & $13(43.3 \%)$ \\
Symptomatic uremia & $7(23.3 \%)$ \\
Hyperkalemia & $14(46.7 \%)$ \\
Fluid overload & $8(26.7 \%)$ \\
Oliguria & \\
Severe metabolic acidosis & \\
\hline
\end{tabular}

Table2. Outcome of CPD in AKI patients treated with CPD:

\begin{tabular}{|c|c|c|}
\hline \multirow[b]{2}{*}{ Complications } & Peritonitis & $6 / 30(20 \%)$ \\
\hline & $\begin{array}{l}\text { Pericatheter } \\
\text { Leakage } \\
\text { Pericatheter } \\
\text { blockage }\end{array}$ & $\begin{array}{l}5 / 30(16.7 \%) \\
4 / 30 \\
(13.33 \%)\end{array}$ \\
\hline \multirow{2}{*}{ Outcome } & $\begin{array}{l}\text { No recovery of } \\
\text { renal function }\end{array}$ & $\begin{array}{l}11 / 27 \\
(40.7 \%)\end{array}$ \\
\hline & $\begin{array}{l}\text { Recovery of } \\
\text { renal function }\end{array}$ & $\begin{array}{l}16 / 27 \\
(59.3 \%)\end{array}$ \\
\hline Death & \multirow{2}{*}{\multicolumn{2}{|c|}{$3 / 30(10 \%)$}} \\
\hline $\begin{array}{l}\text { Weekly Kt/V } \\
\text { urea }\end{array}$ & & \\
\hline
\end{tabular}

Table3. Number of sessions of CPD required for correction of Renal Function.

\begin{tabular}{|l|l|l|}
\hline \multirow{4}{*}{$\begin{array}{l}\text { Session } \\
\text { required for } \\
\text { correction }\end{array}$} & S. Creatinine & $7.5 \pm 1.43$ \\
\cline { 2 - 3 } & S. Urea & $7.3 \pm 1.12$ \\
\cline { 2 - 3 } & S. Potassium & $2.15 \pm 0.69$ \\
\cline { 2 - 3 } & $\begin{array}{l}\text { Severe metabolic } \\
\text { acidosis }\end{array}$ & $2.50 \pm 0.76$ \\
\hline
\end{tabular}

Table4. Follow up of AKI patient treated with CPD:

\begin{tabular}{|l|c|c|}
\hline \multicolumn{1}{|c|}{ Time } & \multicolumn{2}{|c|}{ S. Creatinine $\mu \mathrm{mol} / \mathrm{L}$} \\
\hline & Recovery & No recovery \\
\hline At the end of 4 week & 282.4 & 632.3 \\
\hline At the end of 8 week & 260.7 & 686.6 \\
\hline At the end of 12 week & 230.6 & 672.8 \\
\hline
\end{tabular}

\section{DISCUSSION}

In this study, patients required 6 to 10 sessions of CPD for stabilization of serum creatinine and with the average number of sessions required being $7.5 \pm 1.43$ (mean \pm SD). Gabriel et $\mathrm{al}^{3}$ conducted a prospective study on $30 \mathrm{AKI}$ patients who underwent continuous peritoneal dialysis. In their study serum creatinine became stabilized after 4 sessions. Similar outcomes were observed in studies conducted by Scott $\mathrm{D}$ et $\mathrm{al}^{4}$. In another study, Phu et $\mathrm{al}^{5}$ and Bazari et $\mathrm{al}{ }^{6}$ reported that acidosis could not be controlled by IPD because diaphragm mobilization was impaired by PD and causing increase intra-abdominal pressure and pulmonary ventilation and compliance. In our study, sessions required for correction of 
hyperkalemia \& metabolic acidosis were $2.1 \pm 0.69$ and $2.5 \pm 0.76$ (mean \pm SD). A prospective study on 204 AKI patients who received continuous peritoneal dialysis conducted by Ponce et $\mathrm{al}^{7}$ where exchanges were given by a automated cycler, serum potassium was normalized after one session, $\mathrm{pH}$ and bicarbonate after the second session. Similar outcomes were observed by Cibele P et $\mathrm{al}^{8}$. In this study comparatively more sessions were required for achieving targeted serum creatinine, serum potassium and $\mathrm{pH}$. The reason might be due to relatively less volume of fluid used and automated cyclers being unavailable in our country. .

Chitalia et $\mathrm{al}^{9}$ compared two modalities for treating AKI in moderately catabolic patients in a crossover study. Manual PD achieved a weekly Kt/V urea of 1.8 and tidal PD a weekly Kt/V urea of 2.43 and 86 of the 87 patients recovered renal function. The International Society of Peritoneal Dialysis (ISPD) guidelines, for acute kidney injury 2014, recommended that a weekly Kt/V urea of 2.1 may be acceptable. In our study the delivered weekly $\mathrm{Kt} / \mathrm{V}$ urea was $1.95 \pm 0.14$ (mean $\pm \mathrm{SD})$.

Infection occurred in 6(20.0\%) patients in the form of peritonitis and the organisms were Pseudomonas auriginosa, Eecherischia coli and Staphylococcus aureus. There was no exit site or tunnel infection. In the study of Brett et $\mathrm{al}^{10} 12 \%$ patients had peritonitis. Kajiru Gad Kilonzo et a ${ }^{11}$ showed peritonitis to occur in up to $12 \%$ of cases within first 48 hours of therapy. During this study pericatheter leakage occurred in 5(16.7\%) patients. M Leblanc et $\mathrm{al}^{12}$ conducted similar study where pericatheter leakage was observed in more than $5 \%$ of cases.

Among thirty patients, fourteen recovered renal function and fifteen had to continue CPD at the time of discharge and one expired. The patients who continued dialysis after discharge, two recovered renal function later and two died. The outcome at the end of study period $10 \%$ died, 59.3\% had recovered renal function and rest did not recovered.

A study by Chionh et $\mathrm{al}^{13}$ on 150 AKI patients who had undergone CPD showed that $57.3 \%$ died, $23 \%$ recovered renal function and $6.6 \%$ remain on dialysis on hospital discharge. Compared to this study mortality rate was lower in our study. As this was a single center study done in a short period of time, all the results were not consistent with similar studies. Considering the limitations of this study, it may be recommended that further large scale multi center randomized controlled trials of larger duration including comparison of continuous ambulatory peritoneal dialysis with different other modalities of renal replacement therapy may be done in AKI patients.

\section{CONCLUSION:}

Continuous peritoneal dialysis was effective in correction of metabolic and electrolyte imbalance. Adequate and gradual reduction of serum creatinine and urea within an acceptable time span could be achieved with favorable outcome and minimal complications. Thus it can be used as an alternative to other form of RRT in AKI.

\section{REFRENCES:}

1. Brady HR, Clarkson MR, Lieberthal W. Acute renal failure. Benner \& Rector's the Kidney. 6th ed. 2000; 1201-62.

2. George J, Varma S, Kumar S, Thomas J, Gopi S, Pisharody R: Comparing continuous venovenous hemodiafiltration and peritoneal dialysis in critically ill patients with acute kidney injury: a pilot study. Perit Dial Int 2011; 31:422-9

3. Gabriel DP, Nascimento GV, Caramori JT, Martim LC, Barretti P, Balbi AL. Peritoneal dialysis in acute renal failure. Peritoneal Dialysis International. 2006; 28: 451-56.

4. Scott D. Bieber, John Burkart, Thomas A. Golper, Isaac Teitelbaum, Melhotra R, et al. Comparative Outcomes Between Continuous Ambulatory and Automated Peritoneal Dialysis: A Narrative Review. AJKD 2014:63: 6: 1027-1037.

5. Phu NH, Hien TT, Mai NTH et al. Hemofiltration and peritoneal dialysis in infection associated acute renal failure in Vietnam. New England Journal of Medicine, 2002; 347: 895-902.

6. Bazari H. Hemofiltration and peritoneal dialysis in infection-associated acute renal failure. New England Journal of Medicine 2003; 348:858-60.

7. Ponce D, Marina Nogueira Berbel, Cassiana Regina de Goes, Cibele Taís Puato Almeida, André Luís Balbi. High-Volume Peritoneal Dialysis in Acute Kidney Injury: Indications and Limitations. CJASN June 07, 2012; vol. 7 no. 6 887-894 
8. Cibele Puato Almeida, Daniela Ponce, Ana

Carolina de Marchi, Andre Luis Balbi et al. Effect of Peritoneal Dialysis on Respiratory Mechanics in Acute Kidney Injury Patients. Perit Dial Int JulyAugust 2014 34:544-549.

9. Chitalia VC, Almeida AF, Rai $\mathrm{H}$ et al. Is peritoneal dialysis adequate for hypercatabolic acute renal failure in developing countries? Kidney International 2002; 61(2): 747-57.

10. Brett Cullis, Mohamed Abdelraheem, Georgi Abrahams, Andre Balbi, et al. Peritoneal Dialysis for Acute Kidney Injury. Perit Dial Int 2014:34: 5: 494-517

11. Kajiru Gad Kilonzo, Sudakshina Ghosh, Siya Anaeli Temu, Venance Maro et al. Outcome of Acute Peritoneal Dialysis in Northern Tanzania. Perit Dial Int May-June 2012 32:261-266.

12. M Leblanc, D Ouimet et al. Dialysate leaks in peritoneal Dialysis. Semin Dial 2001 JanFeb;14(1):50-4

13. Chionh CY, Ronco C, Finkelstein FO, Soni SS, Cruz DN. Use of peritoneal dialysis in AKI: a systematic review. Clinical Journal of American Society of Nephrology. 2013; 8(10): 1649-60 